\title{
Investigation of genotoxicity risk and DNA repair capacity in breast cancer patients using anastrozole
}

\author{
Tugce Yesil Devecioglu, ${ }^{1}$ Fatih Aydogan, ${ }^{2}$ Gulden Zehra Omurtag, ${ }^{3}$ Nuran Senel Bese, ${ }^{4}$ Semra Sardas ${ }^{1}$ \\ ${ }^{1}$ Department of Pharmaceutical Toxicology, Marmara University Faculty of Pharmacy, Istanbul, Turkey \\ ${ }^{2}$ Department of General Surgery Service of Breast Diseases, Istanbul University Cerrahpasa Faculty of Medicine, Istanbul, Turkey \\ ${ }^{3}$ Departmen of Pharmaceutical Toxicology, Medipol University Faculty of Pharmacy, Istanbul, Turkey \\ ${ }^{4}$ Department of Radiation Oncology, Acıbadem University Faculty of Medicine, Istanbul, Turkey
}

\begin{abstract}
OBJECTIVE: Breast cancer is the most common cancer in women worldwide and the incidence increases in postmenopausal women. Anastrozole is a non-steroidal (type II), third-generation aromatase inhibitor (AI) that is used in the treatment of postmenopausal estrogen-related breast cancer. Several studies have been conducted to assess the efficacy, safety, and superiority of AIs to tamoxifen; however, a literature search did not reveal a study that investigated the genotoxic potential of AIs. The aim of this study was to investigate the possible DNA damage risk profile and individual DNA repair capacity of patients using anastrozole with the modified alkaline comet assay in order to contribute to public health and health economics.

METHODS: Women diagnosed with breast cancer after menopause comprised the study group. Six patients who had taken anastrozole for at least 6 months were retrospectively enrolled, and 12 patients who had not yet received treatment were prospectively enrolled as a control group. Peripheral blood lymphocytes were used to measure oxidized DNA damage using formamidopyrimidine DNA-glycosylase (FPG) and endonuclease III (endo III) in a modified comet assay. Individual DNA repair capacity was evaluated with the comet assay after a hydrogen peroxide $\left(\mathrm{H}_{2} \mathrm{O}_{2}\right)$ challenge to examine the difference in DNA damage susceptibility.

RESULTS: Analysis of DNA damage, oxidative base damage, susceptibility to DNA damage, and repair capacity revealed no significant difference between the control group and the patients taking anastrozole $(p>0.05)$. Susceptibility to $\mathrm{H}_{2} \mathrm{O}_{2}$ damage was observed to increase with age $(p<0.05)$.

CONCLUSION: According to the results obtained in this study, anastrozole did not contribute to oxidative DNA damage. An $\mathrm{H}_{2} \mathrm{O}_{2}$ challenge with the comet assay is useful to evaluate circumstances of increased vulnerability to damage, such as aging and cancer.

Keywords: Anastrozole; aromatase inhibitors; DNA damage; DNA repair capacity; modified comet assay.
\end{abstract}

$\mathrm{B}$ reast cancer is the second most frequently encountered type of cancer in both developed and developing countries, and it is the cancer seen most often in women. In 2012, 1.67 million new cases of breast cancer were recorded in the world, which amounted to some $25 \%$ of all cancer cases. Overall, breast cancer ranks fifth among causes of cancer-related death; however, it is first among cancer-related deaths in women. The incidence of breast cancer demonstrates regional differences: in Africa and Eastern Asia, the incidence is $27 / 100.000$, while in Western Europe the incidence has been reported to be $96 / 100.000$, and the rate is higher in developed countries than in developing countries [1]. In our country, in 2014, the incidence was reported to be $43 / 100.000$ [2]. Early menarche, late menopause, obesity, age at first instance of giving birth, and duration of breastfeeding are among the most important known risk factors for breast cancer, since the extent and duration of exposure to estrogen

Received: June 22, 2017 Accepted: August 21, 2017 Online: January 22, 2018

Correspondence: Dr. Tugce YESİL DEVECİGLU. Marmara Universitesi Eczacillk Fakultesi Farmasotik Toksikoloji Anabilim Dali, Istanbul, Turkey. Tel: +90 2164142962 - 1200 e-mail: tugceyesil@gmail.com

(c) Copyright 2018 by Istanbul Provincial Directorate of Health - Available online at www.northclinist.com 
have been demonstrated to play a role [3-7]. The target of endocrine therapy is to decrease estrogenic stimulation of cancer cells. Two basic approaches in endocrine therapy are the use of selective estrogen receptor modulators (SERMs) and estrogen antagonists in order to regulate the activity of estrogen receptors, and aromatase inhibitors (AIs) to inhibit estrogen synthesis [8]. AIs are classified according to their chemical structure as Type I (steroidal), androstenedione derivatives binding irreversibly to aromatase, and Type II (nonsteroidal), those that competitively bind to the heme component of the aromatase-CYP complex. Three generations of AI drugs are currently on the market: the first-generation (Type I: testolactone and Type II: aminoglutethimide), second-generation (Type I: formestane and Type II: fadrozole), and third-generation AIs (Type I: anastrozole and letrozole, and steroid analogue Type II: exemestane) AIs have frequently been used in clinics for endocrine therapy of hormone-dependent breast cancer patients in the postmenopausal period [9-11].

Previously, as first-line treatment, or in the adjuvant treatment of advanced stage breast cancer, the antiestrogen tamoxifen was extensively used; however, since the 2000s, AIs have also been widely used. Tamoxifen is a SERM that inhibits the mitogenic effects of estrogen and competes with estrogen to bind to estrogen receptors. Tamoxifen has been reported to decrease the recurrence rate of early stage breast cancer and the incidence of breast cancer in higher risk women, and to increase overall survival time in premenopausal and postmenopausal women. However, the partial agonistic activity of tamoxifen and its adverse effects when used for more than 5 years (including endometrial cancer, pulmonary embolism, and stroke) have led to a decrease in use. In estrogen-receptor positive breast cancer patients, a significant (50-60\%) decrease in the beneficial effects of tamoxifen over time suggests a development of resistance to tamoxifen [9]. For these reasons, new agents that will block the mitogenic effects of estrogen with greater efficacy and safety are needed. Beginning in 2000, various randomized, clinical studies have been published comparing the effectiveness and safety of AIs with tamoxifen in the treatment of breast cancer [9]. It has been reported that AIs were found to be superior to tamoxifen in many ways, including improvement in disease-free survival and recurrence rates (however, length of overall survival did not differ), though with different side-effect profiles. Long-term use of AIs led to noteworthy side effects, including complaints related to the musculoskeletal system and the cardiovascular system [12-16].

In recent years, a growing number of biomonitoring studies have been performed to investigate the genotoxic effects of various xenobiotics, aiming at risk evaluation [17]. The comet assay is a sensitive, reliable technique, easily and rapidly applied to various tissue/special cell types, and it has gradually found widespread use in human biomonitoring studies. The broad potential application of the comet assay and the results obtained contribute to risk definition (i.e., potential genotoxic/mutagenic potential of an agent for humans), dose-response evaluation (the relationship between the dose of the substance and the possibility of inducing an adverse effect), and understanding the mechanism of activity of the substance $[17,18]$. Using the technique developed by Singh et al. [19], DNA-DNA, DNA-protein cross-links of spiral strand breaks, and alkali-labile regions can be detected. Collins et al. [20, 21] incorporated lesion-specific, baseextraction enzymes (endonuclease III [endo III] and formamidopyrimidine DNA glycosylase [Fpg]) into the protocol of this technique, which enabled the identification of oxidized DNA bases (modified comet assay) [20, 21]. The comet technique can be used to measure DNA repair capacity: cells are challenged using a DNA-damaging chemical or physical agents are incubated to determine the susceptibility of the cells to damage and the rate of repair [22].

Several views have been presented regarding the widespread use of AIs [23-25]. The genotoxicity of tamoxifen has been investigated in many studies [29]. However, a literature review revealed no study thus far that has investigated the genotoxic effects of AIs. Therefore, the aim of the present study was to evaluate the genotoxicity risk of a third-generation AI, anastrozole, which is used in the endocrine therapy of breast cancer in postmenopausal women, and to assess any effect on susceptibility to DNA damage.

\section{MATERIALS AND METHODS}

\section{Study groups}

Postmenopausal women diagnosed with breast cancer between 2009 and 2012 in the Department of General Surgery, Service of Breast Diseases were enrolled in the study. A control group consisting of 12 treatment-naive patients diagnosed with breast cancer was prospectively enrolled upon diagnosis. The study group was selected from patients who had used anastrozole for at least 6 months $(n=6)$. The groups were consistent with regard to age, smoking history, antioxidant use, and family history of cancer. The demographic characteristics of the patients are presented in Table 1 . 
TABLE 1. Demographic characteristics of the study group and the control group

\begin{tabular}{|c|c|c|c|}
\hline Groups & Control (\%) & Study (\%) & $\mathrm{p}$ \\
\hline $\mathrm{N}$ & 12 & 6 & \\
\hline Mean age $( \pm S D)$ (years) & $54.42 \pm 12.95$ & $60 \pm 9.65$ & $p>0.05$ \\
\hline \multicolumn{4}{|l|}{ Smoking } \\
\hline Smoker (n/day) & $2(16.67)$ & $1(16.67)$ & \multirow{2}{*}{$p>0.05$} \\
\hline Nonsmoker & $10(83.33)$ & $5(83.33)$ & \\
\hline \multicolumn{4}{|l|}{ Family history of cancer } \\
\hline Yes & $3(25)$ & $4(66.67)$ & \multirow{2}{*}{$p>0.05$} \\
\hline No & $9(75)$ & $2(33.33)$ & \\
\hline \multicolumn{4}{|l|}{ Antioxidant use } \\
\hline Yes & $1(8.33)$ & $1(16.67)$ & \multirow{2}{*}{$p>0.05$} \\
\hline No & $11(91.67)$ & $5(83.33)$ & \\
\hline \multicolumn{4}{|l|}{ Prescription drug use } \\
\hline Yes & $7(58.33)$ & $6(100)$ & \multirow{2}{*}{$p>0.05$} \\
\hline No & 5 (41.67) & 0 & \\
\hline
\end{tabular}

The Ethics Committee for Clinical Investigations of the Istanbul University Cerrahpaşa Faculty of Medicine approved the study and its compliance with the Helsinki Declaration (no: 13726). The study participants were informed about the research and provided written, informed consent.

Collection of blood samples, and isolation of lymphocytes After completing a questionnaire, 2-mL blood samples were collected in heparinized tubes from each patient and processed the same day. To isolate the lymphocytes, $100 \mu \mathrm{L}$ of blood was suspended in $1 \mathrm{~mL}$ of phosphate buffered saline, and $100 \mu \mathrm{L}$ of Histopaque (SigmaAldrich, St. Louis, MO, USA) cell separation medium was added. The cells were centrifuged at $250 \mathrm{x}$ g at $4^{\circ} \mathrm{C}$ for 5 minutes. A trypan blue exclusion test of cell viability was performed, and a viability rate of $\geq 99 \%$ was detected.

Measurement of oxidative base damage with modified comet assay using bacterial repair enzymes and determination of hydrogen peroxide-induced damage sensitivity and repair capacity

The comet assay developed by Singh et al. [19] as modified by Collins et al. [20] with Fpg and endo III restriction enzymes was used to determine oxidative base damage. The enzymes were purchased from Dr. Andrew Collins (University of Oslo, Oslo, Norway). The lymphocytes were suspended in $0.65 \%$ low melting point agarose, and then spread on slides coated with $0.65 \%$ high melting point agarose and covered with a coverslip and allowed to solidify. Once solidified, the coverslip was removed and the slides were left overnight in cold lysis solution (stock lysis solution: ph 10:5 M sodium chloride, $100 \mathrm{mM}$ EDTA, $10 \mathrm{mM}$ Tris; on the day of the analysis: $1 \%$ Triton $\mathrm{X}-100$ and $10 \%$ fresh dimethyl sulphoxide solution were added) to lyse the cells. After lysis, slides used to evaluate oxidative damage were incubated with Fpg to identify oxidized purine bases, and with endo III to detect oxidized pyrimidine bases at $37^{\circ} \mathrm{C}$ ambient temperature. To determine susceptibility to DNA damage and evaluation of DNA repair, labeled lymphocyte samples were treated with $100 \mu \mathrm{M}$ hydrogen peroxide $\left(\mathrm{H}_{2} \mathrm{O}_{2}\right)$, rinsed, and incubated at $37^{\circ} \mathrm{C}$. The procedure used to assess oxidative purine and pyrimidine damage, susceptibility to DNA damage, and DNA repair capacity, as well as the formulas used in the calculations are summarized in Table 2. The protocol was performed in a dark room following lysis. To ensure the unwinding of DNA double strands, the slides were placed in $1 \mathrm{mM}$ EDTA, $300 \mathrm{mM}$ sodium hydroxide $\mathrm{pH}>13$ for 40 minutes and then subjected to electrophoresis at $15 \mathrm{~V}$ and an electrical current of $300 \mathrm{~mA}$ for 30 minutes. After this phase, neutralization procedures were repeated 3 times for a total of 15 minutes using $0.4 \mathrm{M}$ Tris ( $\mathrm{pH} 7.5)$ buffer solution, and fixed with $50 \%, 75 \%$, or $100 \%$ ethanol. The slides were then stained with $25 \mu \mathrm{g} / \mathrm{mL}$ ethidium respectively bromide and examined under an Olympus BX51 fluorescent microscope (Olympus, Corp., Tokyo, Japan) at 40x magnification. All assessments were performed using the Comet Image Processing and Analysis System software (BAB Bs 200 Pro; BAB Ltd., Ankara, Turkey). For each trial, 50 cells were counted on each of 2 slides. The intensity of DNA (\% DNA) in the tail was used to determine DNA damage. The formulas used to estimate oxidative damage and repair capacity are summarized in Table 2.

\section{Statistical analysis}

The data obtained in this study were analyzed using SPSS Statistics for Windows, Version 17.0 (SPSS, Inc., Chicago, IL, USA). Descriptive statistics of mean, SD, frequency (\%), and the difference between the minimum and maximum values were calculated for the categorical variables of each data group. In the evaluation of DNA repair capacity, in addition to determining the mean, the data were also expressed as median, and 25th and 75th percentile values due to the small sample size. Normal 
TABLE2. Experiment conditions and formulas used to evaluate basal damage, oxidative base damage, susceptibility to DNA damage, and DNA repair capacity

$\begin{array}{ccccc}\text { Enzyme buffer } & \text { Endo III } & \text { FPG } & \text { Basal } & \\ \text { (1/3000 dilution) } & \text { (1/3000 dilution) } & \text { damage } & \begin{array}{c}\mathrm{H}_{2} \mathrm{O}_{2} \text {-induced } \\ \text { damage } \\ \text { (final concentration } \\ 100 \mu \mathrm{M})\end{array} & \text { Repair }\end{array}$

\begin{tabular}{|c|c|c|c|c|c|c|}
\hline $\begin{array}{l}\text { Duration of incubation/exposure } \\
\text { and ambient temperature }\end{array}$ & $\begin{array}{c}45 \mathrm{~min} \\
\left(37^{\circ} \mathrm{C}\right) \\
\text { (A) }\end{array}$ & $\begin{array}{c}45 \min \\
\left(37^{\circ} \mathrm{C}\right) \\
(\mathrm{B})\end{array}$ & $\begin{array}{c}30 \min \\
\left(37^{\circ} \mathrm{C}\right) \\
(\mathrm{C})\end{array}$ & - & $\begin{array}{c}7 \min \\
\left(+4^{\circ} \mathrm{C}\right) \\
(\mathrm{D})\end{array}$ & $\begin{array}{c}60 \min \\
\left(37^{\circ} \mathrm{C}\right) \\
(\mathrm{E})\end{array}$ \\
\hline
\end{tabular}

*each condition was tested using multiple slides $(n=12)$.

Oxidative pyrimidine base damage $=\mathrm{B}-\mathrm{A}$

Oxidative purine base damage $=\mathrm{C}-\mathrm{A}$

DNA repair capacity $(\%)=([D-E] / D) \times 100$

$\mathrm{H}_{2} \mathrm{O}_{2}$ : Hydrogen peroxide; FPG: Formamidopyrimidine DNA-glycosylase

distribution was assessed with the Shapiro-Wilk test. The differences between 2 independent groups that did not have normal distribution were measured using the Mann-Whitney U test. A chi-square test was employed to investigate the intergroup distribution of demographic findings. Since $20 \%$ of the values in the table were less than 5, Fisher's exact test was performed. The correlation between effects of age and duration of anastrozole use determined in the comet assay and DNA repair capacity as estimated using the challenge technique was measured with Spearman's rank correlation analysis. Spearman's rank correlation analysis was also used to determine the relationships between methods. $\mathrm{P}<0.05$ was accepted as the level of statistical significance.

\section{RESULTS}

There was no statistically significant difference in basal damage determined with the comet assay between the study group $(10.52 \pm 2.11)$ and the control group $(12.54 \pm 2.61)(p>0.05)$ (Table 3$)$. Nor was a statistically significant difference in pyrimidine damage found between the study group $(29.14 \pm 14.48)$ and the control group (25.45 \pm 23.46$)$. Comparison of purine damage also revealed no statistically significant difference between the study group $(25.63 \pm 10.51)$ and the control group $(14.71 \pm 8.38)(p>0.05)$ (Table 3$)$. Furthermore, no statistically significant difference was found between the study group and the control group in terms of susceptibility to $\mathrm{H}_{2} \mathrm{O}_{2}$ damage with the challenge assay (40.96 $\pm 14.5,36.52 \pm 10.81$, respectively), residual damage after 1 hour of incubation $(22.47 \pm 6.37,22.58 \pm 9.20$,

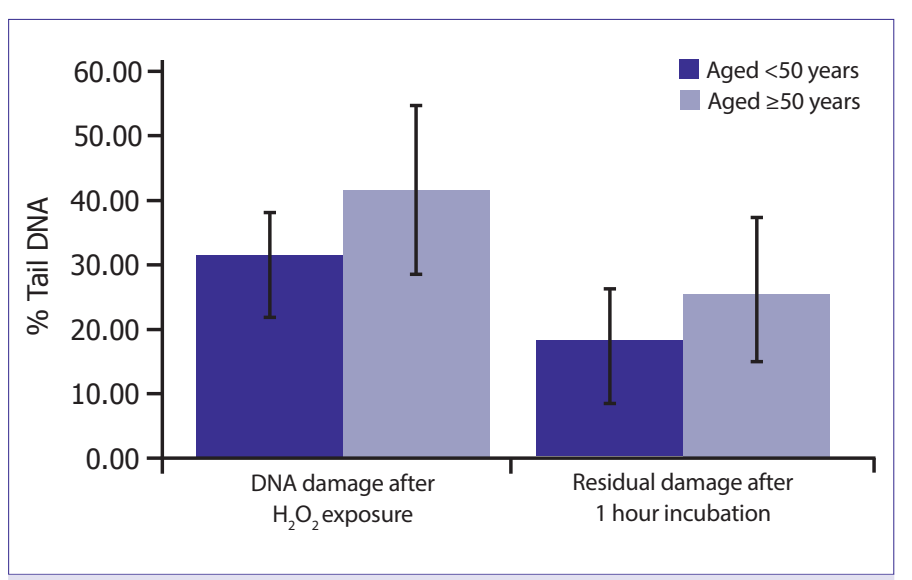

FIGURE 1. Hydrogen peroxide sensitivity and residual damage in individuals aged $<50$ and $\geq 50$ years in all groups (mean $\pm \mathrm{SD}$ ). $* \mathrm{P}<0.05$.

respectively), or DNA repair capacity $(42.73 \pm 11.28$, $38.43 \pm 12.59$, respectively) ( $>0.05$ ) (Table 3).

When groups were compared based on participant age greater than or less than 50 years, susceptibility to $\mathrm{H}_{2} \mathrm{O}_{2}$ damage ( $<50$ years: $30.67 \pm 8.31, \geq 50$ years: $41.67 \pm 12.01)$ and residual damage after 1 hour of incubation ( $<50$ years: $17.38 \pm 4.05, \geq 50$ years: $25.12 \pm 8.59$ ) were found to be statistically significantly greater in individuals aged $\geq 50$ years $(\mathrm{p}<0.05)$. Comparisons performed for susceptibility to $\mathrm{H}_{2} \mathrm{O}_{2}$ damage and DNA repair capacity of individuals between individuals aged $<50$ and $\geq 50$ years are shown in Figure 1.

When other variables that could affect the results were analyzed, a statistically significant correlation was not found between the modified comet and challenge as- 
TABLE 3. Parameters of damage, repair, and susceptibility to damage in the control and study groups

\begin{tabular}{|c|c|c|c|c|c|}
\hline & $\mathrm{n}$ & Mean \pm SD & Median & $\begin{array}{l}\text { 25th percentile } \\
\text { 75th percentile }\end{array}$ & $\mathrm{p}$ \\
\hline \multicolumn{6}{|l|}{ Basal damage (\% DNA) } \\
\hline All patients & 18 & $11.87 \pm 2.59$ & 11.74 & $\begin{array}{c}9.94 \\
13.15\end{array}$ & $p>0.05$ \\
\hline Group Study & 6 & $10.52 \pm 2.11$ & 10.32 & $\begin{array}{c}9.09 \\
11.79\end{array}$ & \\
\hline Control & 12 & $12.54 \pm 2.61$ & 12.45 & $\begin{array}{l}11.21 \\
13.74\end{array}$ & \\
\hline \multicolumn{6}{|c|}{ Pyrimidine damage (\% DNA) } \\
\hline All patients & 18 & $26.68 \pm 20.52$ & 18.02 & $\begin{array}{l}10.39 \\
37.43\end{array}$ & $p>0.05$ \\
\hline Group Study & 6 & $29.14 \pm 14.48$ & 29.06 & $\begin{array}{c}17.8 \\
38.25\end{array}$ & \\
\hline Control & 12 & $25.45 \pm 23.46$ & 13.67 & $\begin{array}{c}9.55 \\
45.29\end{array}$ & \\
\hline \multicolumn{6}{|l|}{ Purine damage (\% DNA) } \\
\hline All patients & 18 & $18.56 \pm 10.36$ & 12.83 & $\begin{array}{l}10.93 \\
26.42\end{array}$ & $p>0.05$ \\
\hline Group Study & 6 & $25.63 \pm 10.51$ & 26.42 & $\begin{array}{l}17.75 \\
32.33\end{array}$ & \\
\hline Control & 12 & $14.71 \pm 8.38$ & 12.13 & $\begin{array}{l}10.23 \\
15.75\end{array}$ & \\
\hline \multicolumn{6}{|l|}{$\begin{array}{l}\text { DNA damage induced by } \\
\mathrm{H}_{2} \mathrm{O}_{2}(\% \text { DNA) }\end{array}$} \\
\hline All patients & 18 & $38 \pm 11.92$ & 35.2 & $\begin{array}{l}26.56 \\
48.73\end{array}$ & $p>0.05$ \\
\hline Group Study & 6 & $40.96 \pm 14.5$ & 43.14 & $\begin{array}{c}24.59 \\
53.5\end{array}$ & \\
\hline Control & 12 & $36.52 \pm 10.81$ & 33.05 & $\begin{array}{l}27.65 \\
45.44\end{array}$ & \\
\hline \multicolumn{6}{|c|}{ DNA repair capacity (\% DNA) } \\
\hline All patients & 18 & $39.86 \pm 12.02$ & 36.72 & $\begin{array}{l}30.91 \\
44.89\end{array}$ & $\mathrm{p}>0.05$ \\
\hline Group Study & 6 & $42.73 \pm 11.28$ & 43.65 & $\begin{array}{l}33.76 \\
51.39\end{array}$ & \\
\hline Control & 12 & $38.43 \pm 12.59$ & 34.66 & $\begin{array}{l}30.25 \\
43.33\end{array}$ & \\
\hline
\end{tabular}

say values for the duration of anastrozole use ( $p>0.05)$. Analysis of age in the modified comet and challenge assay results revealed that in the control group, age was related to basal damage $(\mathrm{r}=0.713 ; \mathrm{p}<0.01)$. No correlation was observed between age and other parameters for the whole group or between groups $(p>0.05)$. When the measured variables were compared with one another, a correlation was found between susceptibility to $\mathrm{H}_{2} \mathrm{O}_{2}$ damage and residual damage (damage after 1 hour of incubation) $(r=0.754 ; p<0.01)$.

\section{DISCUSSION}

Breast cancer is the most prevalent cancer type in women in both developed and developing countries. AIs rank first for adjuvant treatment of postmenopausal estrogen-dependent breast cancer; they inhibit aromatase enzymes, which catalyze the last phase of the biosynthesis of estrogen, aromatization [10, 27]. Anastrozole is a potent, selective, and nonsteroidal third-generation (Type II) AI. Investigation of the side effect profiles of AIs revealed that these molecules cause a significant in- 
crease in bone loss and bone fractures, and a decrease in bone mineral density. When tamoxifen and AIs were compared, the cardiovascular risk of AIs use was found to be statistically significantly higher. In addition, musculoskeletal symptoms, as joint pain, were observed in nearly half of patients $[12-16,28,29]$.

Many researchers have offered different opinions about the popularization of AIs. Seruga and Tannock [24] reported that the treatment goal for any type or stage of cancer is to increase survival time and quality of life, and if an inexpensive and established treatment like tamoxifen is to be replaced with a more costly new alternative, then the new treatment should be more effective in at least 1 of those targets. This report is an important subject of debate. Montemurro and Aglietta stated that tamoxifen is still a good adjuvant endocrine treatment for early stage, postmenopausal, hormone receptor-positive breast cancer, but indicated that AIs are superior in terms of antitumor activity and lower toxicity profile [23]. Based on the outcomes of their randomized phase III trials, Yamamoto and Iwase [25] reported that AIs are more effective than tamoxifen in the treatment of early breast cancer, but also noted that the safety profiles are quite different. For instance, a recent meta-analysis demonstrated that tamoxifen may have a more favorable safety profile with respect to cardiotoxicity [30]. Numerous studies are being performed regarding the effectiveness and reliability of AIs. However, a review of the literature did not yield a study that investigated the impact of AIs on DNA. Therefore, we aimed to investigate the effect of one AI, anastrozole, on DNA.

In the present study, postmenopausal patients with a diagnosis of breast cancer who were using anastrozole were compared with treatment-naive postmenopausal women with breast cancer, and the effect (if any) of anastrozole on oxidative base damage was investigated using a modified comet assay. In addition, susceptibility to DNA damage induced by a $\mathrm{H}_{2} \mathrm{O}_{2}$ challenge assay and DNA repair capacity were compared.

Lymphocytes, which are easily obtained with noninvasive methods, are most often used in biomonitoring studies [31]. These cells are synchronous with the G0 phase of the cell cycle. Their most important characteristic feature is that their biological effects are manifest in target organs because they circulate in the blood throughout the body. Therefore, they are frequently preferred for monitoring DNA damage and chromosomal aberrations with the goal of evaluating the risk of genotoxicity [32].

We also used lymphocytes isolated from peripheral blood samples of our volunteer patients. We did not find any statistically significant difference between patients using anastrozole and the control group according to results of the conventional comet assay examining peripheral blood lymphocytes $(p>0.05)$. Furthermore, application of the modified comet assay did not reveal any statistically significant difference with respect to pyrimidine or purine damage $(p>0.05)$.

To our knowledge, there is no study investigating the potential role of anastrozole in DNA damage. Wozniak et al. [26] investigated the genotoxic effect of tamoxifen with the modified comet assay (using endo III and Fpg enzymes) and found that tamoxifen increased the comet parameters in peripheral blood lymphocytes and Michigan Cancer Foundation-7 breast cancer cells. Liu et al. [33] also investigated DNA damage induced by tamoxifen metabolites in breast cancer cell lines using the comet assay and reported that catechol metabolites induced more severe DNA damage.

In our study, we did not find a statistically significant difference between the study group and the control group in susceptibility to $\mathrm{H}_{2} \mathrm{O}_{2}$ damage incurred during 1 hour of incubation (residual damage) or DNA repair capacity (\%) following the $\mathrm{H}_{2} \mathrm{O}_{2}$ challenge assay $(\mathrm{p}>0.05)$. We observed that the sensitivity to $\mathrm{H}_{2} \mathrm{O}_{2}$ damage demonstrated great interindividual difference. We think that this may reveal individual differences in cellular susceptibility to the agent we used. Similarly, Sterpone et al. [34] used radiation as a challenge agent and reported great variation in damage in all groups, which they related to potential individual genetic sensitivities independent of cancer.

In our study, we compared groups $<50$ and $\geq 50$ years of age, and found a statistically significantly higher susceptibility to $\mathrm{H}_{2} \mathrm{O}_{2}$ damage and residual damage in individuals aged $\geq 50$ years $(p<0.05)$. It was observed that DNA repair capacity had decreased, though not significantly, and that DNA damage and oxidative base damage had increased. Piperakis et al. [35] also investigated age, DNA damage, and related sensitivities, comparing susceptibility to damage in 3 groups of 20 male participants of distinct age using an alkaline comet assay, $\mathrm{H}_{2} \mathrm{O}_{2}$, and radiation challenge assays. Consistent with our results, the researchers reported that basal damage, residual damage, and sensitivity in the 60-70 years age group were significantly higher compared with that found in groups aged $40-50$ years and 5-10 years, with the smallest values seen in the group aged 5-10 years. Diem et al. [36] also performed a study using an alkaline comet assay and reported increased DNA damage with age.

It is very well known that individual changes in DNA repair capacity affect the predisposition to cancer [21]. 
Not all individuals exposed to the same carcinogen at the same concentration will eventually develop cancer [37]. Individual repair capacity is related to many factors, including genetic and environmental factors, lifestyle-related influences, and dietary habits [21]. This relationship between cancer and susceptibility to DNA damage is also important with respect to cancer treatment, and suggests that the susceptibility of patients to the mutagenic effects of drugs should be better understood.

According to the results we obtained from this study, anastrozole was not seen to have an impact on oxidative DNA damage. The most important limitation of our study was the small number of samples. However, since this was an in vivo study, it was not possible to include a large number of patients who met our criteria. Therefore, in vitro evaluation of the effect of anastrozole on DNA damage may be helpful to further clarify any genotoxic effect. Based on our results, cellular susceptibility to damage increases and the repair process slows with age, which is similar to the findings of other studies. This suggests that the use of an $\mathrm{H}_{2} \mathrm{O}_{2}$ challenge test in combination with the comet assay is useful in the investigation of conditions that increase susceptibility to damage, such as aging and cancer.

Ethics Committee Approval: The Ethics Committee for Clinical Investigations of the Istanbul University Cerrahpaşa Faculty of Medicine approved the study and its compliance with the Helsinki Declaration (no: 13726).

Conflict of Interest: No conflict of interest was declared by the authors.

Financial Disclosure: This study was supported by Research Foundation of Marmara University (grant no: SAG-C-YLP-211009-0313).

Authorship contributions: Concept - T.Y.D., S.S., G.O., N.S.B.; Design - T.Y.D., S.S., G.O., N.S.B.; Supervision - S.S.; Materials F.A., N.S.B.; Data collection \&/or processing - T.Y.D., S.S.; Analysis and/or interpretation - T.Y.D.; Writing - T.Y.D., S.S.; Critical review - T.Y.D., S.S., F.A.

\section{REFERENCES}

1. World Health Organization. International Agency for Research on Cancer 2016. Avaliable at: http://gco.iarc.fr/today/data/pdf/factsheets/cancers/cancer-fact-sheets-15.pdf. Accessed Jun 9, 2017.

2. Bora Başara B, Güler C, Soytutan İ, Aygün A, Özdemir TA, editors. T.C. Sağlık Bakanlığı Sağlık İstatistikleri Yıllığı 2015. Ankara: Türkiye Cumhuriyeti Sağlık Bakanlığı Sağlık Araştırmaları Genel Müdürlüğü, 2016. Available at: http://www.saglikistatistikleri.gov.tr. Accessed Jan 18, 2018.

3. Chang M. Dual roles of estrogen metabolism in mammary carcinogenesis. BMB Rep 2011;44:423-34. [CrossRef]

4. Key TJ, Verkasalo PK, Banks E. Epidemiology of breast cancer. Lancet Oncol 2001;2:133-40. [CrossRef]
5. Key TJ. Endogenous oestrogens and breast cancer risk in premenopausal and postmenopausal women. Steroids 2011;76:812-5. [CrossRef]

6. Travis RC, Key TJ. Oestrogen exposure and breast cancer risk. Breast Cancer Res 2003;5:239-47. [CrossRef]

7. Yager JD, Davidson NE. Estrogen carcinogenesis in breast cancer. N Engl J Med 2006;354:270-82. [CrossRef]

8. Dinçol D, Özal G. Meme kanserinde endokrin tedavi. In: Aydın S, Akça T, editors. Tüm Yönleriyle Meme Kanseri. Adana: Nobel Kitabevi; 2011 p. 389-95.

9. Berry J. Are all aromatase inhibitors the same? A review of controlled clinical trials in breast cancer. Clin Ther 2005;27:1671-84. [CrossRef]

10. Hong Y, Yu B, Sherman M, Yuan YC, Zhou D, Chen S. Molecular basis for the aromatization reaction and exemestane-mediated irreversible inhibition of human aromatase. Mol Endocrinol 2007;21:401-14.

11. Macedo LF, Sabnis G, Brodie A. Aromatase inhibitors and breast cancer. Ann N Y Acad Sci 2009;1155:162-73. [CrossRef]

12. Amir E, Seruga B, Niraula S, Carlsson L, Ocaña A. Toxicity of adjuvant endocrine therapy in postmenopausal breast cancer patients: a systematic review and meta-analysis. J Natl Cancer Inst 2011;103:1299-309.

13. Dent SF, Gaspo R, Kissner M, Pritchard KI. Aromatase inhibitor therapy: toxicities and management strategies in the treatment of postmenopausal women with hormone-sensitive early breast cancer. Breast Cancer Res Treat 2011;126:295-310. [CrossRef]

14. Eisen A, Trudeau M, Shelley W, Messersmith H, Pritchard KI. Aromatase inhibitors in adjuvant therapy for hormone receptor positive breast cancer: a systematic review. Cancer Treat Rev 2008;34:157-74.

15. Files JA, Ko MG, Pruthi S. Managing aromatase inhibitors in breast cancer survivors: not just for oncologists. Mayo Clin Proc 2010;85:560-6.

16. Rugo HS. The breast cancer continuum in hormone-receptor-positive breast cancer in postmenopausal women: evolving management options focusing on aromatase inhibitors. Ann Oncol 2008;19:16-27. [CrossRef]

17. Brendler-Schwaab S, Hartmann A, Pfuhler S, Speit G. The in vivo comet assay: use and status in genotoxicity testing. Mutagenesis 2005;20:245-54. [CrossRef]

18. Decordier I, Loock KV, Kirsch-Volders M. Phenotyping for DNA repair capacity. Mutat Res 2010;705:107-29. [CrossRef]

19. Singh NP, McCoy MT, Tice RR, Schneider EL. A simple technique for quantitation of low levels of DNA damage in individual cells. Exp Cell Res 1988;175:184-91. [CrossRef]

20. Collins AR, Duthie SJ, Dobson VL. Direct enzymic detection of endogenous oxidative base damage in human lymphocyte DNA. Carcinogenesis 1993;14:1733-5. [CrossRef]

21. Collins AR. Investigating oxidative DNA damage and its repair using the comet assay. Mutat Res 2009;681:24-32. [CrossRef]

22. Collins AR, Azqueta A. DNA repair as a biomarker in human biomonitoring studies; further applications of the comet assay. Mutat Res 2012;736:122-9. [CrossRef]

23. Montemurro F, Aglietta M, Del Mastro L. Aromatase inhibitors as adjuvant therapy for breast cancer. J Clin Oncol 2009;27:2566-7. [CrossRef]

24. Seruga B, Tannock IF. Up-front use of aromatase inhibitors as adjuvant therapy for breast cancer: the emperor has no clothes. J Clin Oncol 2009;27:840-2. [CrossRef]

25. Yamamoto Y, Iwase H. Safety profiles of aromatase inhibitors and selective estrogen-receptor modulators in the treatment of early breast cancer. Int J Clin Oncol 2008;13:384-94. [CrossRef]

26. Wozniak K, Kolacinska A, Blasinska-Morawiec M, Morawiec-Bajda A, 
Morawiec Z, Zadrozny M, et al. The DNA-damaging potential of tamoxifen in breast cancer and normal cells. Arch Toxicol 2007;81:519-27.

27. Choueiri TK, Alemany CA, Abou-Jawde RM, Budd GT. Role of aromatase inhibitors in the treatment of breast cancer. Clin Ther 2004;26:1199-214. [CrossRef]

28. Thorne C. Management of arthralgias associated with aromatase inhibitor therapy. Curr Oncol 2007;14 Suppl 1:S11-9. [CrossRef]

29. Gangadhara S, Bertelli G. Long-term efficacy and safety of anastrozole for adjuvant treatment of early breast cancer in postmenopausal women. Ther Clin Risk Manag 2009;5:291-300.

30. Foglietta J, Inno A, de Iuliis F, Sini V, Duranti S, Turazza M, et al. Cardiotoxicity of Aromatase Inhibitors in Breast Cancer Patients. Clin Breast Cancer 2017;17:11-7. [CrossRef]

31. Au WW, Oberheitmann B, Harms C. Assessing DNA damage and health risk using biomarkers. Mutat Res 2002;509:153-63. [CrossRef]

32. Cebulska-Wasilewska A. Response to challenging dose of X-rays as a pre- dictive assay for molecular epidemiology. Mutat Res 2003;544:289-97.

33. Liu X, Pisha E, Tonetti DA, Yao D, Li Y, Yao J, et al. Antiestrogenic and DNA damaging effects induced by tamoxifen and toremifene metabolites. Chem Res Toxicol 2003;16:832-7. [CrossRef]

34. Sterpone S, Cornetta T, Padua L, Mastellone V, Giammarino D, Testa A, et al. DNA repair capacity and acute radiotherapy adverse effects in Italian breast cancer patients. Mutat Res 2010;684:43-8. [CrossRef]

35. Piperakis SM, Kontogianni K, Karanastasi G, Iakovidou-Kritsi Z, Piperakis MM. The use of comet assay in measuring DNA damage and repair efficiency in child, adult, and old age populations. Cell Biol Toxicol 2009;25:65-71. [CrossRef]

36. Diem E, Ivancsits S, Rüdiger HW. Basal levels of DNA strand breaks in human leukocytes determined by comet assay. J Toxicol Environ Health A 2002;65:641-8. [CrossRef]

37. Au WW. Abnormal chromosome repair and risk of developing cancer. Environ Health Perspect 1993;101 Suppl 3:303-8. [CrossRef] 